\title{
Techniques for Increasing Machine Harvest Efficiency in Highbush Blueberry
}

\author{
Fumiomi Takeda ${ }^{1,7}$, Gerard Krewer ${ }^{2,5}$, Changying $\mathrm{Li}^{3}$, \\ Daniel MacLean ${ }^{2,6}$, and James W. Olmstead ${ }^{4}$
}

AdDitional INDEX WORDs. Vaccinium, ground loss, bruise, impact damage, catch plate, crown restriction, sparkleberry, rabbiteye

Summary. Northern highbush (NH) blueberry (Vaccinium corymbosum) and southern highbush $(\mathrm{SH})$ blueberry ( $V$. corymbosum hybrids) have fruit that vary in firmness. The SH fruit is mostly hand harvested for the fresh market. Hand harvesting is labor-intensive requiring more than $\mathbf{5 0 0}$ hours/acre. Rabbiteye blueberry ( $V$. virgatum) tends to have firmer fruit skin than that of $\mathrm{NH}$ blueberry and has been mostly machine harvested for the processing industry. Sparkleberry ( $V$. arboreum) has very firm fruit. With the challenges of labor availability, efforts are under way to produce more marketable fruit using machine harvesting. This could require changing the design of harvesting machine and plant architecture, and the development of cultivars with fruit that will bruise less after impact with hard surfaces of machines. The objectives of this study were to determine the fruit quality of machine-harvested SH blueberry, analyze the effect of drop height and padding the contact surface on fruit quality, investigate the effect of crown restriction on ground loss, and determine the effect of plant size on machine harvestability. The fruit of 'Farthing', 'Scintilla', 'Sweetcrisp', and several selections were either hand harvested or machine harvested and assessed during postharvest storage for bruise damage and softening. Machine harvesting contributed to bruise damage in the fruit and softening in storage. The fruit of firm-textured SH blueberry ('Farthing', 'Sweetcrisp', and selection FL 05-528) was firmer than that of 'Scintilla' after 1 week in cold storage. Fruit drop tests from a height of 20 and 40 inches on a plastic surface showed that 'Scintilla' was more susceptible to bruising than that of firmtextured 'Farthing' and 'Sweetcrisp'. When the contact surface was cushioned with a foam sheet, bruise incidence was significantly reduced in all SH blueberry used in the study. Also, the fruit dropped 40 inches developed more bruise damage than those dropped 20 inches. Ground loss during machine harvesting was reduced from $24 \%$ to $17 \%$ by modifying the rabbiteye blueberry plant architecture. Further modifications to harvesting machines and plant architecture are necessary to improve the quality of machine-harvested SH and rabbiteye blueberry fruit and the overall efficiency of blueberry (Vaccinium species and hybrids) harvesting machines.

$P^{b}$ urrent world highbush blueberry ( $V$. corymbosum) acreage is about four times more than it was in 1995. In 2005, world blueberry production was 431 million pounds and is projected to grow to about 1.5 billion pounds by 2015 (Villata, 2012). The blueberry industry in the United States has developed effective market promotion programs to increase consumption based on health reputation. For the U.S. blueberry industry to remain competitive and maintain profitability for its growers, timely fruit harvest must be addressed. The costs of labor and production are projected to increase while the price for blueberries is projected to decrease (Strik and Yarborough, 2005). Brown et al. (1996) reported that because of the poor quality of $\mathrm{NH}$ blueberry in Michigan, most fruit going to the fresh market had to be hand harvested or had to be consumed within a few days of machine harvest. Blueberry production remains profitable, but the price has declined, particularly in the traditional high-value months of April and May. Hand harvest produces high fruit quality but at the high cost of labor. In the southeastern United States, hand harvesting costs $\$ 0.50 / \mathrm{lb}$ to $\$ 0.70 / \mathrm{lb}$ for $\mathrm{SH}$ blueberry and somewhat less for rabbiteye blueberry (Safley et al., $2005)$. The machine harvesting cost for fruit destined for the processing industry is estimated to be about $\$ 0.12 / 1 b$. Availability of a work force for harvesting is expected to be a major challenge to the U.S. highbush blueberry industry.

A key step to addressing this challenge is to advance the machine harvest technologies. Harvesting machines improve labor productivity by nearly 60 times while cutting the harvest cost by $85 \%$ (Brown et al., 1983). In the southeastern United States, most blueberry harvesting machines are currently used for the processing market and not for harvesting fruit for fresh market (Table l) because the fruit of SH blueberry that have been machine harvested become much softer than hand-harvested fruit during postharvest storage. The key constraints to a wider use of machines to harvest SH blueberry for fresh market are as follows:

Damage occurring during harvest, particularly bruising lowers overall quality by producing softer, leaky fruit that are at increased risk of decay during postharvest handling and storage (Ballinger et al., 1973; Dale et al., 1994; Funt et al., 1998; Mehra et al., 2013; Miller and Smittle, 1987; NeSmith et al., 2002). Furthermore, bruising often results in a loss of the visually appealing fruit surface wax (bloom), thereby further decreasing quality (Dale et al., 1994). Stem tearing, a third important type of damage, occurs when machine harvesting operations result in the forceful removal of the fruit from the pedicel. These injuries increased postharvest moisture loss and the fruit were

\begin{tabular}{llll}
\hline $\begin{array}{l}\text { Units } \\
\text { To convert U.S. to SI, } \\
\text { multiply by }\end{array}$ & U.S. unit & SI unit & $\begin{array}{l}\text { To convert SI to U.S., } \\
\text { multiply by }\end{array}$ \\
\hline 0.4047 & acre $(\mathrm{s})$ & $\mathrm{ha}$ & 2.4711 \\
0.3048 & $\mathrm{ft}$ & $\mathrm{m}$ & 3.2808 \\
3.7854 & $\mathrm{gal}$ & $\mathrm{L}$ & 0.2642 \\
2.54 & inch $(\mathrm{es})$ & $\mathrm{cm}$ & 0.3937 \\
0.4536 & $\mathrm{lb}$ & $\mathrm{kg}$ & 2.2046 \\
1.1209 & $\mathrm{lb} / \mathrm{acre}$ & $\mathrm{kg} \cdot \mathrm{ha}^{-1}$ & 0.8922 \\
1.6093 & $\mathrm{mph}$ & $\mathrm{km} \cdot \mathrm{h}^{-1}$ & 0.6214 \\
28.3495 & $\mathrm{oz}$ & $\mathrm{g}$ & 0.0353 \\
1.1161 & $\mathrm{oz} / \mathrm{inch}$ & $\mathrm{g} \cdot \mathrm{mm}^{-1}$ & 0.8960 \\
0.4732 & $\mathrm{pt}$ & $\mathrm{L}$ & 2.1134 \\
$\left({ }^{\circ} \mathrm{F}-32\right) \div 1.8$ & ${ }^{\circ} \mathrm{F}$ & ${ }^{\circ} \mathrm{C}$ & $\left({ }^{\circ} \mathrm{C} \times 1.8\right)+32$
\end{tabular}


Table 1. Estimated percentage of southern highbush ( $\mathrm{SH})$ blueberry acreage in several states in the southeastern United States that is machine harvested at least once per season for the fresh market.

\begin{tabular}{lcc}
\hline State $^{\mathrm{z}}$ & $\begin{array}{c}\text { Production } \\
\text { area } \\
\text { (acres) }^{\mathrm{y}}\end{array}$ & $\begin{array}{c}\text { Machine } \\
\text { harvested } \\
\text { area (\%) }\end{array}$ \\
\hline Florida & 3800 & $<5$ \\
Georgia & 2250 & 1 \\
North Carolina & 5500 & 20 \\
\hline
\end{tabular}

${ }^{\mathrm{z}}$ In Florida and Georgia, blueberry acreage consists of SH blueberry cultivars (D. Stanaland, personal communication; J.G. Williamson, personal communication). In North Carolina, the blueberry acreage consists of more northern highbush blueberry than SH blueberry (W.O. Cline, personal communication). ${ }^{y} 1$ acre $=0.4047$ ha.

particularly prone to infection by fruitdecay fungi (Ceponis and Cappellini, 1979).

Excessive ground loss; i.e., fruit are detached during the harvesting processes but are missed by the catch plates (also called fish scales) at the base of the machine. These losses often have reached $20 \%$ to $30 \%$ with machine harvesting (Mainland, 1993; Strik and Buller, 2002; van Dalfsen and Gaye, 1999).

Excessive green and red fruit detachment results in yield loss and increased sorting cost in the packinghouse. To reduce the proportion of green and red fruit in the harvested product, the first picking by machine is usually delayed by 5 to $7 \mathrm{~d}$ relative to hand harvesting. Delaying the harvesting of SH blueberry when the prices are

This paper was part of the workshop "Mechanized Harvest of Blueberries for the Fresh Market" held 2 Aug. 2012 at the ASHS Conference, Miami, FL, and sponsored by the Viticulture and Small Fruits (VSF) Working Group

The funding for this study is provided by the USDA Specialty Crop Research Initiative, NIFA Award Number 2008-51180-19579.

We gratefully acknowledge the support and assistance of Gary Burnham, Breyn Evans, Ann Rose, Harald Scherm, Alto Straughn, Pengcheng Yu, Paul Lyrene, and Kim Hummer.

${ }^{1}$ Appalachian Fruit Research Station, U.S. Department of Agriculture, Agricultural Research Service, 2217 Wiltshire Road, Kearneysville, WV 25430

${ }^{2}$ Department of Horticulture, University of Georgia, Tifton Campus, 2360 Rainwater Road, Tifton, GA 31793

${ }^{3}$ College of Engineering, 712F Boyd Graduate Studies, University of Georgia, Athens, GA 30602

${ }^{4}$ Horticultural Sciences Department, 2211 Fifield Hall, University of Florida, Gainesville, FL 32611

${ }^{5}$ Current address: Krewer Consulting, LLC, 550 Mary's Drive, Woodbine, GA 31569

${ }^{6}$ Current address: AgroFresh, Inc., 620 Cantrill Drive, Davis, CA 95618

${ }^{7}$ Corresponding author. E-mail: fumi.takeda@ars.usda. gov. rapidly declining as volume is increasing is not desirable.

Mature fruit missed by the machine, results in overripe fruit by the next harvest 2 to $3 \mathrm{~d}$ later (Mainland, 1993; Strik and Buller, 2002). Most commonly, such missed fruit in rabbiteye blueberry were on upright canes in the center of the bush (Takeda et al., 2008).

In approaching the first constraint of damaging fruit, research has shown that softening in machineharvested fruit can be reduced if the drop height can be maintained at less than 24 inches (Brown et al., 1996). Fruit picking machines such as the V45 blueberry harvester (BEI, South Haven, MI) were designed to minimize drop height and reduce ground loss (Peterson et al., 1997). However, the V45 blueberry harvester has not been widely accepted commercially due to machine design that limits operating speed and durability and because it requires special cane training and pruning (Takeda et al., 2008). The second, third, and fourth constraints have stimulated innovations in cultural practices for improving machine harvest efficiency. These practices have been focused primarily on minimizing ground loss and reducing the number of mature fruit missed by the machine (Peterson et al., 1997; Takeda et al., 2008). Strik and Buller (2002) in Oregon showed that supporting 'Bluecrop', an NH blueberry, with a simple two-wire trellis system increased harvest efficiency significantly, mainly by reducing the number of mature fruit missed by the machine. The maximum proportion of fruit remaining after the last machine harvest was reduced from $30.8 \%$ in not-trellised plots to $15.5 \%$ in trellised plots with canes kept more upright by trellis wires.

SH blueberry plants in areas with warm, long growing season tend to produce fewer, major upright canes that reach larger diameters than the blueberry plants in colder climates with short growing season (G. Krewer, personal observation). A trellis installation technique that would reposition the canes away from the center of the bush and toward the outside of the canopy where fruit would be more easily detached by the machine appears to be advantageous for SH blueberry. This technique could reduce the proportion of fruit missed by the machine in the bush center. As an additional benefit, such repositioning would allow better sunlight penetration into the interior of the bush for flower bud formation and increased yields. Yáñez et al. (2009) reported that low sunlight levels caused the interior fruit twigs to set fewer flower buds, and as the light levels drop below $20 \%$ of full sunlight these shoots eventually die. However, the effect of pruning and trellising the remaining canes has not been studied for ground loss.

Ground loss associated with the use of machine can be significant, reaching up to $30 \%$ of the total crop (Mainland, 1993). Even with wellpruned bushes, losses of $20 \%$ have been documented (Strik and Buller 2002; van Dalfsen and Gaye, 1999). In early season fresh market sales when the blueberry price can be over $\$ 5 / \mathrm{lb}$, the $\mathrm{SH}$ blueberry growers in the southeastern United States could lose over $600 \mathrm{lb} /$ acre in ground loss if bushes are harvested entirely with a machine.

Machines operate by passing over the plant row and agitating the bushes on both sides to detach fruit. At the same time, spring-loaded catch plates surround the base of the plant at 12-to 18 -inch height to catch the falling fruit and guide them to conveyor belts. Because the crown of $\mathrm{SH}$ blueberry plants consists of multiple canes that tend to spread out at the height where the fish scales meet the bush, gaps form between the canes and the fish scales, resulting in machine-detached fruit that fall to the ground (Fig. 1). Although these losses can be reduced somewhat by pruning as the bushes age, the crown diameter is difficult to maintain to less than 8 to 12 inches at the 18 -inch height. By installing crown-restricting tubing made from 6-inch plastic drainpipe around the canes of young blueberry plants, Rohrbach and Mainland (1989) were able to reduce ground loss by $40 \%$ compared with untreated bushes. However, suckering of the canes was increased at the point where the tubing met the soil, and plant mortality tended to be higher in plots with the tubing. Furthermore, infestation by fire ants (Solenopsis invicta), an important nuisance pest in the southern United States (Scherm et al., 2001), was exacerbated. Alternative approaches for crown restriction without these drawbacks need to be developed and evaluated. 
Trellised with a collar Free-standing

(crown restriction)

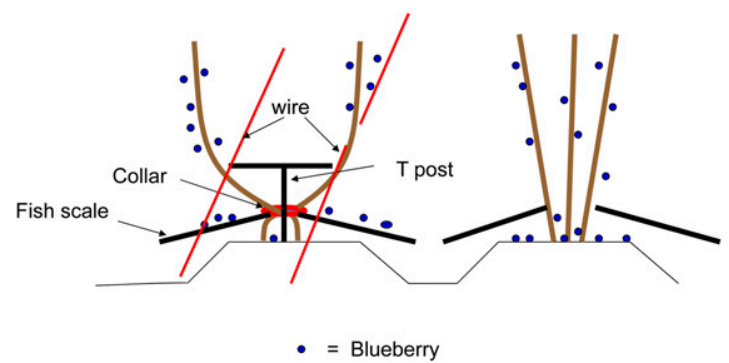

Fig. 1. Schematic illustration of crown restriction and trellis installation treatments to facilitate machine harvest. (Left) A blueberry plant with its crown constricted with a collar and the branches spread on a $T$-post. The branches were positioned outside the two wires, one at each end of the horizontal bar on top of the post. Note that the cross-sectional area where the fish scales contact the crown is smaller on the plant with a collar. (Right) Free-standing plant (not-trellised and notconstricted crown). Note the large gap between the fish scales where machinedetached blueberry fruit can fall through.

We performed four studies. The objectives of our studies were to 1 ) determine the fruit quality of machineharvested SH blueberry, 2) analyze the effect of drop height and padding the contact surface on fruit quality, 3) investigate the effect of crown restriction on ground loss, and 4) determine the effect of plant size on machine harvestability.

\section{Materials and methods}

MACHINE HARVESTING OF SH BLUEBERRY. In 2009 and 2010, field experiments were conducted at Straughn Farms in Waldo, FL, to evaluate $\mathrm{SH}$ cultivars and advanced selections. Plants were harvested either by hand or with a Korban 8000 harvester (Oxbo, Lynden, WA) and assessed for yield, harvest efficiency, and a range of fruit quality measurements $\mathrm{l} d$ at room temperature $\left(72^{\circ} \mathrm{F}\right)$ and after 1 week in cold storage $\left(36^{\circ} \mathrm{F}\right)$. 'Sweetcrisp', 'Farthing', and selections FL 98-325 and FL 05-290 were considered to be firm-textured; e.g., having a crisp-textured fruit (Padley, 2005; Padley and Lyrene, 2006). 'Star', 'Primadonna', 'Scintilla', and selection FL 05-486 were described as having a soft-textured fruit.

Four sections (20 plants per section) of each $\mathrm{SH}$ blueberry were harvested by hand or with a self-propelled rotary machine in late Apr. 2009 and early May 2010. The machine was operated at the ground speed of 0.7 to $1.0 \mathrm{mph}$ with the shaking rods vibrating between 10.7 and $11.5 \mathrm{~Hz}$.
The operating parameters were optimized for each cultivar or selection with the aid of a technician/driver provided by the manufacturer. In both years, hand harvesting consisted of gently removing ripe fruit using thumb and fingers and placing into l-gal buckets. Fruit harvested by the machine was collected into standard blueberry lugs $(24 \times 14 \times 7$ inches $)$. Harvested fruit was weighed and transported in a trailer maintained at $59^{\circ} \mathrm{F}$ to a packing house in Alapaha, GA where a packing line with a lift belt, an air blower to remove leaves and twigs, a tilted belt to remove green clusters and heavily damaged fruit, an inspection table to grade fruit manually for size and color [U.S. Department of Agriculture (USDA), 1996], and a filler to feed fruit into 1-pt clamshells was used. Clamshells containing fruit were transported to Tifton, GA, where they were placed in cold storage at $36^{\circ} \mathrm{F}$. Fruit were removed from cold storage after $7 \mathrm{~d}$ and firmness was measured on a sample of 50 fruit per replication using a FirmTech 2 instrument (Bioworks, Wamego, KS) and assessed for internal bruise damage.

DROP TESTS AND INTERNAL BRUISING. In 2010, hand-harvested fruit of 'Farthing', 'Scintilla', 'Sweetcrisp', and selections FL 05-264 and FL 05-290 were used in a drop test. Hand-harvested fruit were dropped into l-gal bucket from a height of $\mathrm{l} \mathrm{ft}$. Fifty fruit of each $\mathrm{SH}$ cultivar and selection were sliced through the fruit along the equatorial axis within $2 \mathrm{~h}$ of harvesting. Four lots of 50 fruit were dropped from a height of 2 or $4 \mathrm{ft}$ onto a hard or soft contact surface to simulate machine harvest operation. The dropped fruit were kept either at room temperature $\left(72{ }^{\circ} \mathrm{F}\right)$ for $24 \mathrm{~h}$ or for $7 \mathrm{~d}$ in cold storage $\left(36^{\circ} \mathrm{F}\right)$ and then sliced through the fruit along the equatorial axis to determine the percentage of cut surface area that showed water-soaked cells, darkened tissue, or both.

In 2011 , SH blueberry cultivars (Farthing, Primadonna, Scintilla, Sweetcrisp) and selections (FL 05528, FL 06-556) and a cultivar with sparkleberry in its pedigree (Meadowlark) were used in a drop test. Handharvested fruit were dropped from a height of 20 or 40 inches onto a hard or soft contact surface and evaluated for internal bruise damage after $\mathrm{l} d$ at room temperature $\left(72^{\circ} \mathrm{F}\right)$ and after $7 \mathrm{~d}$ in cold storage $\left(36^{\circ} \mathrm{F}\right)$ for firmness and internal bruise damage. Fruit were sliced along the equatorial axis and the percentage of cut surface area with discolored and water-soaked tissue was determined by two evaluators.

Ground Loss. Trellis and crown restriction treatments were applied in an existing 3-year-old planting of 'Premier' rabbiteye blueberry at a commercial farm in Homerville, GA (Fig. 1) in Feb. 2010. There were four replications of 20-plant plots for each of three treatments: 1) conventional winter pruning for hand-harvest (Takeda et al., 2008), 2) crown restriction at 18 -inch height with heavyduty zip-ties, and 3 ) crown restriction plus a T-post trellis at 24 -inch height. Contact herbicides and pruning were used to keep the canes within bounds on plants in the latter two treatments. The purpose of Treatment 2 was to reduce the diameter of the crown from over 12 to 6 inches to allow the machine's fish scales to seal better and reduce gaps between the canes and catching surface. The purpose of Treatment 3 was to constrict the crown, spread the bearing surfaces away from the crown, and then position canes to outside of trellis wires at the ends of the cross-arm. This arrangement was implemented with the purpose of simultaneously minimizing ground loss and the proportion of mature fruit missed by the machine. The T-bar on the trellis was 20 -inch wide so that trellis components would not interfere with the machine's rotating shaker/beater rods. 
The plots were machine harvested in 2009 and 2010 using a rotary machine (Korban 8000) operated by the owner of the farm. Machine-harvested fruit was weighed and after each harvest, all fruit on the ground beneath the plants was counted to determine ground loss.

Plant Size and fruit Removal. Five- to 6-year-old (6-ft-tall) $\mathrm{SH}$ blueberry plants of 'Primadonna', 'Sweetcrisp', and FL 98-325 and 3-year-old (3-4 ft tall) plants of 'Farthing', 'Scintilla', 'Star', FL 05-290, and FL 05486 were machine harvested in 2009. Fruit clusters located in the top, middle, and bottom third of 6 -ft-tall plants and top half and bottom half of 3- to 4-ft-tall plants were tagged and the number of green, red, and blue fruit were counted before and after machine harvest.

\section{Results and discussion}

Machine HaRvesting OF SH BLUEBERRY. Quality evaluations (Table 2 ) showed that the fruit size ranged from $1.6 \mathrm{~g} /$ fruit for 'Primadonna' to $2.4 \mathrm{~g} /$ fruit for 'Scintilla'. Firm-textured SH blueberry generally had a greater amount of fruit meeting the U.S. No.l grade standard (USDA, 1996) than that of the soft-textured $\mathrm{SH}$ blueberry. Percentage of stemmed fruit ranged between $2.0 \%$ and $4.9 \%$ in eight $\mathrm{SH}$ cultivars and selections tested except for the selection FL 05-486 with $14.5 \%$ of fruit with a stem. The soft fruit (firmness value of less than $200 \mathrm{~g} \cdot \mathrm{mm}^{-1}$ ) accounted for less than $2 \%$ in firm-textured $\mathrm{SH}$ blueberry. In the soft-textured $\mathrm{SH}$ blueberry, the soft fruit accounted between $2.4 \%$ and $7.1 \%$ of harvested fruit. Pack-out percentage and the fruit meeting the U.S. No. 1 standard in hand-harvested fruit was generally high with exception of selection FL 05-486 because of the high percentage of stemmed fruit.

Machine harvesting significantly lowered the percentage of fruit meeting the U.S. No. 1 standard, increasing the number of fruit with stems and rated as soft in both firm-textured and soft-textured SH blueberry cultivars and selections. The pack-out percentage was only $78 \%$ in machine-harvested, soft-textured SH blueberry. The reduction in the pack-out percentage in machine-harvested, soft-textured $\mathrm{SH}$ blueberry was a result of greater percentage of fruit picked out as green and red color, stemmed, and being too soft (Table 2).

The firm-textured SH blueberry cultivars (Sweetcrisp and Farthing) have been characterized as firmer than those cultivars with soft-textured fruit of 'Scintilla' that has been described as having a melting flesh texture (Padley, 2005; Padley and Lyrene, 2006). The results from this study indicated that hand-harvested fruit of firm-textured $\mathrm{SH}$ blueberry was firmer than that of 'Scintilla' (Table 3 ). For example, hand-harvested fruit of 'Sweetcrisp' had a firmness value of $266 \mathrm{~g} \cdot \mathrm{mm}^{-1}$ before going into cold storage, whereas those of 'Scintilla' had a lower firmness of $216 \mathrm{~g} \cdot \mathrm{mm}^{-1}$ but still in the acceptable range. Also, after $7 \mathrm{~d}$ in cold storage, the machineharvested fruit of firm-textured $\mathrm{SH}$ blueberry had developed bruise damage on $9 \%$ of cut surface area compared with more than $17 \%$ in soft-textured

Table 2. The quality attributes of southern highbush $(\mathrm{SH})$ blueberry. Firmtextured SH blueberry cultivars / selections ('Sweetcrisp', 'Farthing', FL 98-325, FL 05-290) and soft-textured SH blueberry cultivars/selections ('Star', 'Primadonna', 'Scintilla', FL 05-486) were harvested by hand or with a blueberry harvesting machine (Korvan 8000; Oxbo, Lynden, WA) and sorted using the U.S. grade standards (U.S. Department of Agriculture, 1996).

\begin{tabular}{|c|c|c|c|c|c|c|}
\hline \multirow{2}{*}{$\begin{array}{l}\text { SH blueberry } \\
\text { cultivar or } \\
\text { selection }\end{array}$} & \multirow{2}{*}{$\begin{array}{c}\text { Wt } \\
(\mathrm{g} / \text { fruit })^{\mathrm{z}} \\
\end{array}$} & \multirow{2}{*}{$\begin{array}{c}\text { U.S. No. } 1 \\
(\%)^{y}\end{array}$} & \multirow{2}{*}{$\begin{array}{c}\text { Stem } \\
(\%)^{\mathbf{x}}\end{array}$} & \multirow{2}{*}{$\begin{array}{l}\text { Soft } \\
(\%)^{w}\end{array}$} & \multicolumn{2}{|c|}{ Pack-out (\%) } \\
\hline & & & & & Machine & Hand \\
\hline \multicolumn{7}{|l|}{ Firm-textured } \\
\hline Sweetcrisp & $1.9 \mathrm{c}^{\mathrm{v}}$ & $81 \mathrm{~b}$ & $4.9 \mathrm{~b}$ & $0.4 \mathrm{~d}$ & 87 & 86 \\
\hline Farthing & $2.2 \mathrm{~b}$ & $83 \mathrm{~b}$ & $2.0 \mathrm{c}$ & $1.0 \mathrm{~d}$ & 87 & 94 \\
\hline FL 98-325 & $1.9 \mathrm{c}$ & $89 \mathrm{a}$ & $2.8 \mathrm{c}$ & $1.6 \mathrm{~cd}$ & 94 & 94 \\
\hline FL 05-290 & $2.2 \mathrm{~b}$ & $73 \mathrm{c}$ & $3.8 \mathrm{~b}$ & $2.0 \mathrm{~cd}$ & 92 & 95 \\
\hline \multicolumn{7}{|l|}{ Soft-textured } \\
\hline Star & $2.1 \mathrm{bc}$ & $70 \mathrm{c}$ & $2.8 \mathrm{c}$ & $5.5 \mathrm{~b}$ & 70 & 94 \\
\hline Primadonna & $1.6 \mathrm{~d}$ & $76 \mathrm{bc}$ & $3.1 \mathrm{bc}$ & $7.1 \mathrm{a}$ & 90 & 97 \\
\hline Scintilla & $2.4 \mathrm{a}$ & $80 \mathrm{~b}$ & $2.4 \mathrm{c}$ & $2.4 \mathrm{c}$ & 87 & 96 \\
\hline FL 05-486 & $2.0 \mathrm{~b}$ & $64 \mathrm{~d}$ & $14.5 \mathrm{a}$ & $5.3 \mathrm{~b}$ & 68 & 76 \\
\hline \multicolumn{7}{|l|}{ Harvest method } \\
\hline Machine & $2.0 \mathrm{a}$ & $70 \mathrm{~b}$ & $6.0 \mathrm{a}$ & $5.0 \mathrm{a}$ & & \\
\hline Hand & $2.0 \mathrm{a}$ & $84 \mathrm{a}$ & $3.0 \mathrm{~b}$ & $1.3 \mathrm{~b}$ & & \\
\hline
\end{tabular}

${ }^{\mathrm{z}} 1 \mathrm{~g}=0.0353 \mathrm{oz}$

yercentage of fruit meeting the U.S. standards for No. 1 grade of blueberries. Percentage values were transformed by arcsine transformation before analysis to determine differences between means.

xPercentage of fruit with the pedicel still attached. Percentage values were transformed by arcsine transformation before analysis to determine differences between means.

wPercentage of overripe or crushed fruit, according to the U.S. standards for grades of blueberries. Percentage values were transformed by arcsine transformation before analysis to determine differences between means.

'Letters following numbers in each column represent differences by the least square means at $P \leq 0.05$

Table 3. Fruit firmness and bruise development after $1 \mathrm{~d}$ at room temperature $\left[72{ }^{\circ} \mathrm{F}\left(22.2^{\circ} \mathrm{C}\right)\right]$ and after $7 \mathrm{~d}$ in cold storage $\left[36^{\circ} \mathrm{F}\left(2.2^{\circ} \mathrm{C}\right)\right]$ in firm-textured and soft-textured southern highbush blueberry cultivars (Farthing, Primadonna, Scintilla, Sweetcrisp) and selections (FL 05-528, FL 06-556) and a cultivar with sparkleberry in its pedigree (Meadowlark). For bruise assessment, fruit were sliced along the equatorial axis and the percentage bruised or discolored area on the cut surface was visually determined by two evaluators.

\begin{tabular}{|c|c|c|c|c|c|c|}
\hline \multirow{2}{*}{$\begin{array}{l}\text { Cultivar or } \\
\text { selection }\end{array}$} & \multicolumn{2}{|c|}{$\begin{array}{l}\text { Firmness } \\
\left(\mathrm{g} \cdot \mathrm{mm}^{-1}\right)^{\mathrm{z}}\end{array}$} & \multicolumn{2}{|c|}{$\begin{array}{c}<25 \% \\
\text { bruising }(\%)^{y}\end{array}$} & \multicolumn{2}{|c|}{$\begin{array}{c}\text { Bruised } \\
\text { area }(\%)^{y}\end{array}$} \\
\hline & $1 \mathrm{~d}$ & $7 \mathrm{~d}$ & $1 \mathrm{~d}$ & $7 \mathrm{~d}$ & $1 \mathrm{~d}$ & $7 d$ \\
\hline Farthing & $264 b^{x}$ & $249 \mathrm{a}$ & $96 \mathrm{ab}$ & $86 \mathrm{ab}$ & $7 \mathrm{a}$ & $14 \mathrm{~b}$ \\
\hline Meadowlark & $285 \mathrm{a}$ & $252 \mathrm{a}$ & $93 \mathrm{~b}$ & $82 \mathrm{bc}$ & $12 \mathrm{~b}$ & $20 \mathrm{a}$ \\
\hline Primadonna & $206 \mathrm{~d}$ & $198 \mathrm{c}$ & $88 \mathrm{bc}$ & $80 \mathrm{bc}$ & $14 \mathrm{~b}$ & $14 \mathrm{~b}$ \\
\hline Scintilla & $216 \mathrm{~d}$ & $179 \mathrm{~d}$ & $85 \mathrm{c}$ & $71 \mathrm{c}$ & $15 \mathrm{~b}$ & $21 \mathrm{a}$ \\
\hline Sweetcrisp & $266 \mathrm{ab}$ & $254 \mathrm{a}$ & $90 \mathrm{bc}$ & $87 \mathrm{ab}$ & $12 \mathrm{~b}$ & $12 \mathrm{~b}$ \\
\hline FL 05-528 & $277 \mathrm{ab}$ & $261 \mathrm{a}$ & $99 \mathrm{ab}$ & $93 \mathrm{a}$ & $6 a$ & $9 \mathrm{c}$ \\
\hline FL 06-556 & $242 \mathrm{c}$ & $235 \mathrm{~b}$ & $99 \mathrm{a}$ & $89 a$ & $4 \mathrm{a}$ & $12 \mathrm{~b}$ \\
\hline
\end{tabular}

${ }^{2}$ Fruit firmness determined with a FirmTech 2 instrument (Bioworks, Wamego, KS); $1 \mathrm{~g} \cdot \mathrm{mm}^{-1}=0.8960 \mathrm{oz} /$ inch. y Data transformed by arcsine transformation before analysis. Untransformed averages are displayed in the table. ${ }^{x}$ Letters following numbers in each column represent differences by the least square means at $P \leq 0.05$. 
SH blueberry cultivars. Additional studies are needed to characterize their softening rates in cold storage.

Fruit firmness of 'Meadowlark' and the firm-textured SH blueberry cultivars/selections (e.g., 'Farthing', 'Sweetcrisp', FL 05-528, and FL 06556) was significantly higher than that of 'Scintilla' and 'Primadonna', which have been described as having a melting flesh texture. Among the firm-textured cultivars and selections, the percentage of fruit with less than $25 \%$ of the cut surface area indicating bruise damage was about $90 \%$. In the soft-textured cultivars only $85 \%$ to $88 \%$ of fruit samples exhibited bruise damage that was less than $25 \%$ of the cut surface area. After $7 \mathrm{~d}$ in cold storage, bruise damage had increased in all cultivars and selections. The average bruised area in sliced fruit samples ranged from $4 \%$ to $6 \%$ in the firm-textured SH blueberry to as high as $15 \%$ in soft-textured $\mathrm{SH}$ cultivars (data not presented).

The firmness of 'Meadowlark' fruit after $7 \mathrm{~d}$ in cold storage was high, but the bruise assessment after $7 \mathrm{~d}$ showed $20 \%$ of cut surface area was water soaked and discolored. In contrast, FL 05-528 and FL 06-556 possessed high fruit firmness, but low incidence of fruit bruising. Some have high firmness at harvest (e.g., 'Sweetcrisp' and 'Meadowlark'), but bruising develops as a result of impact damage. In others (e.g., FL 05-528 and FL 06-556), fruit quality and firmness at harvest was high, and physical damage such as bruising did not develop in cold storage. These findings suggest that some of the new University of Florida blueberry cultivars and selections have potential to be machine harvested.

Blueberry fruit can be easily bruised (Fig. 2) during any stage of machine harvesting and sorting. In addition, the bruising process often results in loss of fruit surface wax (bloom) and thus results in fruit that are darker (Takeda et al., 2008). Funt et al. (1998) reported that harvesting the fruit slightly past their prime maturity with either sway or rotary machine resulted in fruit that were significantly softer than hand-harvested fruit. Moisture loss during storage was greatest in fruit harvested with the sway machine, but the fruit harvested with a rotary machine showed the greatest loss in overall fruit quality.

DROP TESTS AND INTERNAL BRUISING. Bruise assessment shortly after hand-harvesting indicated that the damaged area averaged $3 \%$ and increased to $8 \%$ after $\mathrm{l} d$ at room temperature among the nondropped fruit (Tables 4 and 5). After $7 \mathrm{~d}$ in cold storage, the firmness of fruit dropped onto hard plastic surface and padded surface was 217 and $242 \mathrm{~g} \cdot \mathrm{mm}^{-1}$, respectively, compared with $246 \mathrm{~g} \cdot \mathrm{mm}^{-1}$ for nondropped fruit. The bruised area in fruit dropped onto hard and padded surfaces averaged $20 \%$ and $13 \%$, respectively, compared with only $8 \%$ in nondropped fruit. The heights of drop affected fruit firmness and the extent of tissue damage. The firmness of fruit dropped 20 inches decreased only $3 \%$ during cold storage while that of fruit dropped 40 inches decreased $10 \%$.

Perhaps the most serious limitation to current machine harvesting technology is the damage caused to fruit (Brown et al., 1996). Fresh blueberry fruit are generally consumed whole and not sliced to reveal the fruit flesh. In some fruit crops, the

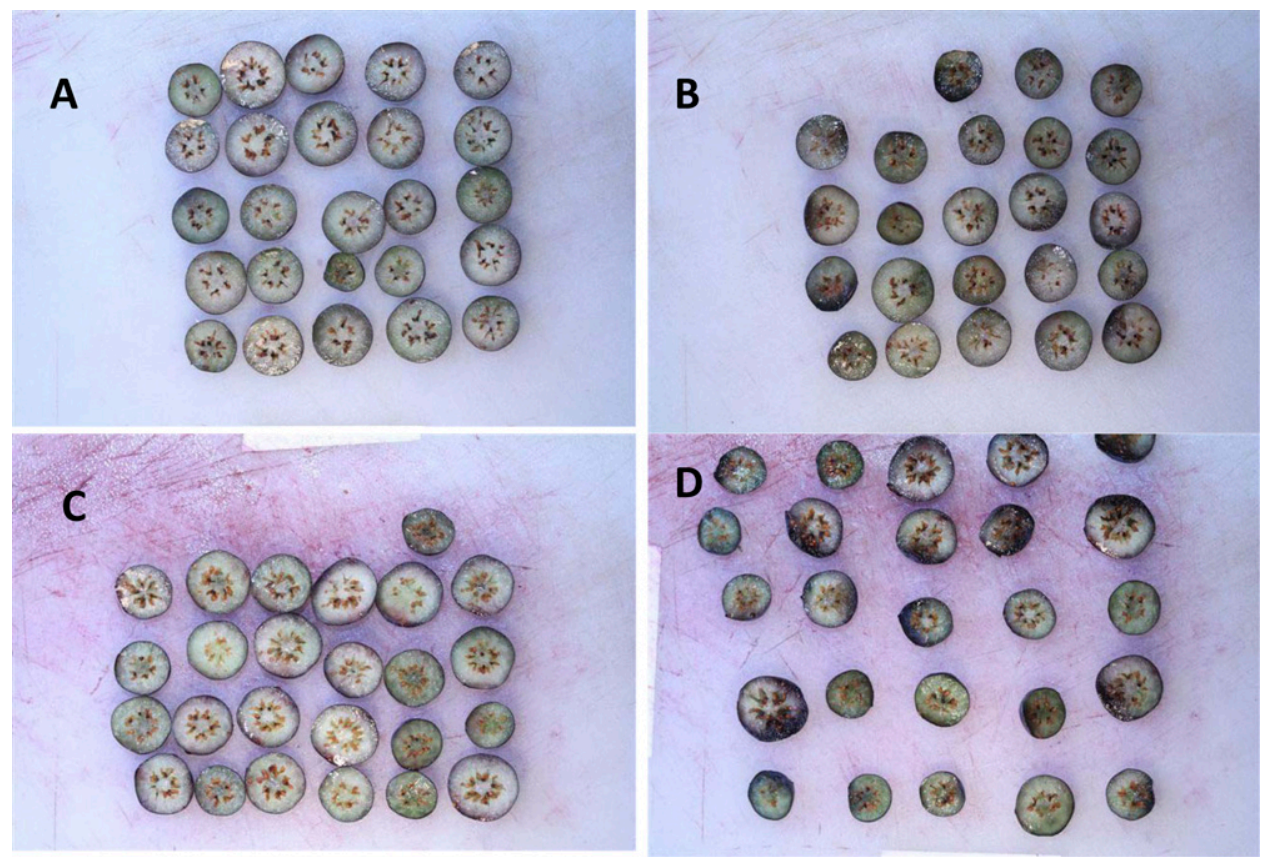

Fig. 2. Internal appearance of southern highbush ( $\mathrm{SH})$ blueberry ('Farthing' and 'Primadonna') fruit after 1 week in cold storage. View of fruit sliced through its center along the equatorial axis after 1 week at $36^{\circ} \mathrm{F}\left(2.2^{\circ} \mathrm{C}\right)$. (A) 'Farthing' (not dropped), (B) 'Farthing' [dropped 40 inches $(101.6 \mathrm{~cm})$ ] to hard surface, (C) 'Primadonna' (not dropped), and (D) 'Primadonna' (dropped 40 inches) to hard surface. Note the visual differences between the firm-textured fruit of 'Farthing' and soft-textured fruit of 'Primadonna'. In both $\mathrm{SH}$ cultivars dropped fruit developed discoloration on one side of the fruit as shown in B and D. Note in D, the sliced fruit of 'Primadonna' that are deformed; e.g., "out of character" or not returning to original round shape. 
Table 4. The influence of dropping onto hard (plastic) and soft foam sheet (NoBruze $^{\circledR}$; Rogers Corp., Woodstock, CT) contacting surfaces on internal fruit bruising after $1 \mathrm{~d}$ at room temperature $\left[72{ }^{\circ} \mathrm{F}\left(22.2^{\circ} \mathrm{C}\right)\right]$ and after $7 \mathrm{~d}$ in cold storage $\left[36^{\circ} \mathrm{F}\left(2.2^{\circ} \mathrm{C}\right)\right]$. The values are the averages of the measurements from southern highbush (SH) blueberry cultivars (Farthing, Primadonna, Scintilla, Sweetcrisp) and selections (FL 05-528, FL 06-556) and cultivar with sparkleberry in its pedigree (Meadowlark). Fruit were dropped from a height of 40 inches $(101.6 \mathrm{~cm})$. For bruise assessment, fruit were sliced along the equatorial axis and the percentage bruised or discolored area on the cut surface was visually determined by two evaluators. Data were combined to show only the main effects.

\begin{tabular}{|c|c|c|c|c|c|}
\hline \multirow[b]{2}{*}{ Material } & \multirow{2}{*}{$\begin{array}{c}\text { Firmness at } 1 \mathrm{~d} \\
\left(\mathrm{~g} \cdot \mathrm{mm}^{-1}\right)^{\mathrm{y}}\end{array}$} & \multicolumn{2}{|c|}{$\begin{array}{c}<25 \% \\
\text { bruising }(\%)^{\mathrm{z}} \\
\end{array}$} & \multicolumn{2}{|c|}{$\begin{array}{l}\text { Bruised } \\
\text { area }(\%)^{\mathrm{z}}\end{array}$} \\
\hline & & $\mathrm{ld}$ & $7 d$ & $\mathrm{ld}$ & $7 \mathrm{~d}$ \\
\hline Control (not dropped) & $246 a^{x}$ & $99 \mathrm{a}$ & $92 \mathrm{a}$ & $3 \mathrm{c}$ & $8 \mathrm{c}$ \\
\hline Plastic & $217 \mathrm{c}$ & $87 \mathrm{c}$ & $76 \mathrm{c}$ & $15 \mathrm{a}$ & $20 \mathrm{a}$ \\
\hline Foam sheet & $242 \mathrm{~b}$ & $95 \mathrm{~b}$ & $87 \mathrm{~b}$ & $8 \mathrm{~b}$ & $13 \mathrm{~b}$ \\
\hline
\end{tabular}

${ }^{z}$ Data transformed by arcsine transformation before analysis. Untransformed averages are displayed in the table. ${ }^{y}$ Fruit firmness was determined with a FirmTech 2 instrument (Bioworks, Wamego, KS); $1 \mathrm{~g} \cdot \mathrm{mm}^{-1}=0.8960 \mathrm{oz}$ / inch.

${ }^{x}$ Letters following numbers in each column represent differences between the least square means at $P \leq 0.05$.

Table 5. The influence of drop heights [ 20 inches and 40 inches $\mathbf{5 0 . 8}$ and $101.6 \mathrm{~cm})]$ on fruit firmness and bruising incidence in southern highbush $(\mathrm{SH})$ blueberry. Internal fruit bruising after $1 \mathrm{~d}$ at room temperature $\left[72^{\circ} \mathrm{F}\right.$ $\left.\left(22.2^{\circ} \mathrm{C}\right)\right]$ and after $7 \mathrm{~d}$ in cold storage $\left[36^{\circ} \mathrm{F}\left(2.2^{\circ} \mathrm{C}\right)\right]$ was determined visually. Fruit were sliced along the equatorial axis and the percentage bruised or discolored area on the cut surface was visually determined by two evaluators. The values are the averages of the measurements from $\mathrm{SH}$ blueberry cultivars (Farthing, Primadonna, Scintilla, Sweetcrisp) and selections (FL 05-528, FL 06-556) and a cultivar with sparkleberry in its pedigree (Meadowlark).

\begin{tabular}{|c|c|c|c|c|c|c|}
\hline \multirow[b]{2}{*}{ Drop ht } & \multirow{2}{*}{$\begin{array}{c}\text { Wt } \\
(\mathrm{g} / \text { fruit })^{\mathrm{z}}\end{array}$} & \multirow{2}{*}{$\begin{array}{l}\text { Firmness after } 7 d \\
\qquad\left(\mathrm{~g} \cdot \mathrm{mm}^{-1}\right)^{\mathrm{y}}\end{array}$} & \multicolumn{2}{|c|}{$\begin{array}{l}\text { Fruit with }<25 \% \\
\text { bruised area }(\%)^{\mathrm{x}}\end{array}$} & \multicolumn{2}{|c|}{$\begin{array}{l}\text { Mean bruised } \\
\text { area }(\%)^{\mathbf{x}}\end{array}$} \\
\hline & & & ld & $7 \mathrm{~d}$ & $1 \mathrm{~d}$ & $7 d$ \\
\hline Not dropped & $1.7 \mathrm{a}^{\mathrm{w}}$ & $246 a$ & $99 \mathrm{a}$ & $92 \mathrm{a}$ & $3 a$ & $8 \mathrm{a}$ \\
\hline 20 inches & $1.6 \mathrm{a}$ & $237 \mathrm{a}$ & $94 \mathrm{~b}$ & $84 \mathrm{~b}$ & $10 \mathrm{~b}$ & $15 \mathrm{~b}$ \\
\hline 40 inches & $1.6 \mathrm{a}$ & $222 \mathrm{~b}$ & $88 \mathrm{c}$ & $79 \mathrm{~b}$ & $14 \mathrm{c}$ & $18 \mathrm{~b}$ \\
\hline
\end{tabular}

${ }^{\mathrm{z}} 1 \mathrm{~g}=0.0353 \mathrm{oz}$.

${ }^{y}$ Fruit firmness was determined with a FirmTech 2 instrument (Bioworks, Wamego, KS); $1 \mathrm{~g} \cdot \mathrm{mm}^{-1}=0.8960 \mathrm{oz} /$ inch.

${ }^{x}$ Data transformed by arcsine transformation before analysis. Untransformed averages are displayed in the table.

wetters following numbers in each column represent differences by the least square means at $P \leq 0.05$.

examination of the flesh is part of the fruit quality evaluation and dark patches or water-soaked areas in the fruit can lead to reduced value. In the case of blueberry, internal tissue damage without the loss of fruit firmness has not led to financial consequences. However, large physical impacts on the fruit can damage cell membranes (Labavitch et al., 1998). When the membranes are damaged, enzymes in the cytoplasm react with phenolics released by the vacuole resulting in the production of dark coloration associated with a bruise. Bruising may also lead to the leakage of cellular water into the cell wall leading to water-soaked areas (Fig. 2) and release of enzymes into the cell wall that can digest the complex molecules of foam sheet $\left(\mathrm{No}^{-B r u z e}{ }^{\circledR}\right.$; Rogers Corp., Woodstock, CT), or catch plates (recessed type) covered with a closedcell foam sheet. Additional padding might be placed in the bottom of the conveyor cups and in the lugs. Foam sheets become torn and cracked after repeated friction with broken blueberry canes and branches. Microbial organisms could harbor in these tears and cracks and raise concerns with food safety. The lack of durability among the foam sheets used to reduce bruise damage has discouraged efforts to install padding material into machines.

Ground Loss. The research showed that 1 year after crown restriction treatment ground loss ranged from $40 \%$ to $42 \%$ for three treatments. The yield in all plots was higher in 2010 compared with 2009. Ground loss in 2010 was significantly reduced by crown restriction treatment (Table 6 ). The use of T-post for spreading the limbs did not reduce ground loss.

Plant SIZE AND FRUIT REMOVAL. In tall plants, less than $15 \%$ of green and red fruit at top, middle, and bottom portions of the plant were detached by the machine (data not presented). The percentage of blue fruit removed ranged from 55\% to $83 \%$ in tall plants, but $<50 \%$ in short plants. These findings agree with grower observations that low fruit harvest efficiency is achieved when young, short plants are machine harvested.

\section{Conclusion}

This study provided evidence that some of the firm-textured $\mathrm{SH}$ blueberry cultivars released in the last 10 years can withstand the physical impacts of machine harvesting better than the soft-textured $\mathrm{SH}$ cultivars. Machine harvesting resulted in softer fruit, presumably through bruising. In storage, machine-harvested fruit lost firmness more rapidly than handharvested fruit. Drop tests showed that both drop height and contact surface material affected the amount of bruising in blueberry fruit. Physical impacts on fruit did not just lead to a cosmetic problem, but they altered the functioning of fruit cells that culminated in internal bruise damage (e.g., watersoaked cells, darkened tissues, or both, and fruit softening). Improved design of harvesting equipment, such as reducing the drop height to less than 15 inches, and horticultural practices, 
Table 6. Effects of canopy management (crown restriction and trellis installation) treatments on 'Premier' rabbiteye blueberry in 2009 on yield and ground losses that occurred during machine harvesting in 2009 and 2010.

\begin{tabular}{lccccc}
\hline & \multicolumn{2}{c}{2009} & & \multicolumn{2}{c}{2010} \\
\cline { 2 - 3 } Treatment & $\begin{array}{c}\text { Harvested } \\
\left(\mathrm{g} / \text { plant }^{\mathrm{z}}\right.\end{array}$ & $\begin{array}{c}\text { Ground } \\
\text { loss (\%) }\end{array}$ & & $\begin{array}{c}\text { Harvested } \\
(\mathrm{g} / \mathrm{plant})\end{array}$ & $\begin{array}{c}\text { Ground } \\
\text { loss (\%) }\end{array}$ \\
\hline Control & $390 \mathrm{a}^{\mathrm{x}}$ & $40 \mathrm{a}$ & & $540 \mathrm{a}$ & $24 \mathrm{a}$ \\
Crown restriction & $424 \mathrm{a}$ & $42 \mathrm{a}$ & & $568 \mathrm{a}$ & $19 \mathrm{~b}$ \\
Crown restriction and trellis & $409 \mathrm{a}$ & $41 \mathrm{a}$ & & $595 \mathrm{a}$ & $17 \mathrm{~b}$ \\
\hline
\end{tabular}

${ }^{2} 1 \mathrm{~g}=0.0353 \mathrm{oz}$.

'Data transformed by arcsine transformation before analysis. Untransformed averages are displayed in the table.

'Letters following numbers in each column represent differences by the least square means at $P \leq 0.05$.

such as crown restriction, will increase harvest efficiency in SH blueberry by capturing more fruit in lugs, leaving less fruit in the field, and maintaining better fruit quality in cold storage. Additional research is necessary to determine how blueberry quality can be affected by physical damage occurring during harvest and packing operations.

\section{Literature cited}

Ballinger, W.E., L.J. Kushmann, and D.D. Hamann. 1973. Factors affecting the firmness of highbush blueberries. J. Amer. Soc. Hort. Sci. 98:583-587.

Brown, G.K., D.E. Marshall, B.R. Tennes, D.E. Booster, P. Chen, R.E. Garrett, M. O'Brien, H.E. Studer, R.A. Kepner, S.L. Hedden, C.E. Hood, D.H. Lenker, W.F. Millier, G.E. Rehkugler, D.L. Peterson, and L.N. Shaw. 1983. Status of harvest mechanization of horticultural crops. Paper No. 83-3. Amer. Soc. Agr. Eng., St. Joseph, MI.

Brown, G.K., N.L. Schulte, E.J. Timms, R.M. Beaudry, D.L. Peterson, J.F. Hancock, and F. Takeda. 1996. Estimates of mechanization effects on fresh blueberry quality. Appl. Eng. Agr. 12:21-26.

Ceponis, M.J. and R.A. Cappellini. 1979. Control of post-harvest decays of blueberry fruit by precooling, fungicide, and modified atmospheres. Plant Dis. Rptr. 63:1049-1053.

Dale, A., E.J. Hanson, D.E. Yarborough, R.J. McNicol, E.J. Stang, R. Brennan, J.R. Morris, and G.B. Hegert. 1994.
Mechanical harvesting of berry crops. Hort. Rev. 16:255-382.

Funt, R.C., T.E. Wall, and J.C. Scheerens. 1998. Yield, berry quality, and economics of mechanical berry harvest in Ohio. Ohio State Univ. Res. Circ. 299-00.

Labavitch, J.M., L.C. Greve, and E. Mitcham. 1998. Fruit bruising: It's more than skin deep. Perishables Handling Qrtly. 95: 7-9.

Mainland, C.M. 1993. Blueberry production strategies. Acta Hort. 346:111-116.

Mehra, L.K., D.D. MacLean, A.T. Savelle, and H. Scherm. 2013. Postharvest disease development on southern highbush blueberry fruit in relation to berry flesh type and harvest method. Plant Dis. 97:213-221.

Miller, W.R. and D.A. Smittle. 1987. Storage quality of hand- and machineharvested rabbiteye blueberries. J. Amer. Soc. Hort. Sci. 112:487-490.

NeSmith, D.S., S. Prussia, M. Tetteh, and G. Krewer. 2002. Firmness losses of rabbiteye blueberries (Vaccinium ashei Reade) during harvesting and handling. Acta Hort. 574:287-293.

Padley, Jr., L. 2005. Firmness and storage characteristics of crisp-textured blueberries. M.S. Thesis, Dept. Hort. Sci., Univ. Florida, Gainesville.

Padley, Jr., L. and P. Lyrene. 2006. Studies with crisp-textured blueberries. HortScience 41:985. (Abstr.).

Peterson, D.L., S.D. Wolford, E.J. Timm, and F. Takeda. 1997. Fresh market qual- ity blueberry harvester. Trans. Amer. Soc. Agr. Eng. 40:535-540.

Rohrbach, R.P. and C.M. Mainland. 1989. Crown restriction in blueberries reduces harvesting ground losses. Paper No. 88-1046. Amer. Soc. Agr. Eng., St. Joseph, MI.

Safley, C.D., W.O. Cline, and C.M. Mainland. 2005. Estimated costs of producing, harvesting, and marketing blueberries in the southeastern United States. Proc. 12th Biennial Southeast Blueberry Conf., Savannah, GA. 33-49.

Scherm, H., D.S. NeSmith, D.L. Horton, and G. Krewer. 2001. A survey of horticultural and pest management practices of the Georgia blueberry industry. Small Fruit Rev. 1:17-28.

Strik, B. and G. Buller. 2002. Improving yield and machine harvest efficiency of 'Bluecrop' through high density planting and trellising. Acta Hort. 574:227231 .

Strik, B. and D. Yarborough. 2005. Blueberry production trends in North America, 1992 to 2003, and predictions for growth. HortTechnology 15:391398.

Takeda, F., G. Krewer, E.L. Andrews, B. Mullinix, and D.L. Peterson. 2008. Assessment of the V-45 blueberry harvester on rabbiteye blueberry and southern highbush blueberry pruned to V-shaped canopy. HortTechnology 18:130-138.

U.S. Department of Agriculture. 1996. United States Standards for Grades of Blueberries. 5 Dec. 2012. <http://www.ams. usda.gov/AMSv1.0/getfile?dDocName= STELPRDC5098169>.

van Dalfsen, K.B. and M.M. Gaye. 1999. Yield from hand and mechanical harvesting of highbush blueberries in British Columbia. Appl. Eng. Agr. 15:393-398.

Villata, M. 2012. Trends in world blueberry production. Amer. Fruit Growers 132(3):30.

Yáñez, P., J.B. Retamales, G.A. Lobos, and A. del Pozo. 2009. Light environment within mature rabbiteye blueberry canopies influence flower bud formation. Acta Hort. 810:471-473. 